\title{
The insecticidal activity of Satureja hortensis L. extracts obtained by supercritical fluid extraction and traditional extraction techniques
}

\author{
Roman Pavela, ${ }^{1, *}$ Marie Sajfrtová, ${ }^{2}$ Helena Sovoví ${ }^{2}$ and Martin Bárnet ${ }^{3}$ \\ ${ }^{1}$ Crop Research Institute; Drnovská 507, Praha 6-Ruzyně, 161 06, Czech Republic \\ ${ }^{2}$ Institute of Chemical Process Fundamentals; Rozvojová 135, 16502 Praha 6-Suchdol, Czech Republic \\ ${ }^{3}$ AGRA GROUP a.s.; Tovární 9, 38715 Střelské Hoštice, Czech Republic
}

(Received 27 August 2007; Accepted 4 March 2008)

\begin{abstract}
The acute toxicity of savory (Satureja hortensis) extracts obtained with supercritical $\mathrm{CO}_{2}$ and by traditional extraction techniques was tested on larvae of Musca domestica, Spodoptera littoralis, Culex quinquefasciatus and Leptinotarsa decemlineata and on adults of $M$. domestica, and the composition of volatile compounds in the extracts was determined. The efficiency of extract obtained with supercritical $\mathrm{CO}_{2}$ at $12 \mathrm{MPa}$ and $50^{\circ} \mathrm{C}$ was comparable with that of hydrodistillate and higher than the efficiency of other extracts, while its extraction yield was by $73 \%$ higher than the yield of hydrodistillate.
\end{abstract}

Key words: Satureja hortensis; SFE; insecticidal activity; botanical insecticides; lethal doses

\section{INTRODUCTION}

Savory (Satureja hortensis L.) is an annual herbaceous plant belonging to the family Lamiaceae (Syn. Labiatae). It is known as summer savory, native to southern Europe and naturalized in parts of North America.

The green leaves and herbaceous parts of stem of $S$. hortensis are used fresh and dried as flavoring agents in seasoning, meat dishes, stews, sausages and vegetables. As a medicinal plant, S. hortensis has been traditionally used as a stomachic, stimulant, expectorant, carminative and aphrodisiac (Sefidkon and Jamzad, 2005; Sefidkon et al., 2004).

The main constituents of $S$. hortensis essential oil are phenols carvacrol and thymol, as well as $\gamma$ terpinene, $p$-cymene, $\beta$-caryophyllene, and other terpenes (Darbour et al., 1990; Sefidkon et al., 2006). Extracts obtained with polar solvents contain polyphenols. The extracts and essential oil have demonstrated antimicrobial and insecticidal activity (Deans and Svoboda, 1989; RegnaultRoger et al., 2004; Pavela, 2006). Thus, they may be a source of alternative agents for control of pests because they are rich in bioactive chemicals, active against a limited numbers of species including specific target insects, and bio-degradable. They are potentially suitable for use in integrated pest management programs (Alkofahi et al., 1989; Pavela, 2007a).

Extraction of these biologically active compounds involves the usage of large amounts of environmentally unfriendly solvents and a number of technological operations. An alternative extraction technique with better efficiency and selectivity, based on alternative solvents, avoiding degradation or loss of sensitive substances and decreasing the high energy and manpower inputs of conventional processes, is highly desired.

Supercritical fluid extraction (SFE) with carbon dioxide as an environmentally benign and efficient extraction technique fulfills these requirements. The solvent is used in supercritical state, under pressure, when its solvation ability becomes similar to that of liquids. The extracted substances separate easily from $\mathrm{CO}_{2}$ as its solvation ability steeply drops after its expansion to gaseous state. Application of SFE for the isolation of biological active compounds from plants has been extensively studied and the interest in the technique has in-

* To whom correspondence should be addressed at: E-mail: pavela@vurv.cz DOI: $10.1303 / \mathrm{aez} .2008 .377$ 
creased in recent years because of legal limitations of solvent residues and solvents. Carbon dioxide is non-toxic, non-flammable, and available in high purity at low cost. It is best suited for the extraction of non-polar components such as hydrocarbons or fatty oils. To dissolve polar components, a polar entrainer (e.g. EtOH, $\mathrm{MeOH}$ ) is added to $\mathrm{CO}_{2}$.

Although the insecticidal properties of savory extract and essential oil are well known (RegnaultRoger et al., 2004; Pavela, 2005; Sampson et al., 2005), no literature exists, to our knowledge, comparing insecticidal effects of different pests and extracts methods. Consequently, the aim of this study was to examine in detail the insecticidal activity of savory extracts obtained by SFE and traditional extraction techniques. In addition, the composition of volatile compounds in the extracts was determined.

\section{MATERIALS AND METHODS}

Plant material. Aerial parts of savory (Satureja hortensis L.: Lamiaceae) were obtained from plant culture of the Crop Research Institute, Prague. They were oven-dried at $40^{\circ} \mathrm{C}$ for $72 \mathrm{~h}$, stored at room temperature and milled prior to extraction experiments. The content of water in the leaves was 7.3 wt. $\%$.

Insects. The housefly Musca domestica L. (Dip., Muscidae), larvae 4th instar and adults 3-4 d old, Spodoptera littoralis (Lep., Noctuidae) (larvae 4th instar, $35 \pm 5 \mathrm{mg}$ weight) and Culex quinquefasciatus Say (Dip.) larvae 4th instar, were obtained from the stock culture maintained in the Crop Research Institute, Dept. of Entomology. Colorado potato beetles Leptinotarsa decemlineata Say (Col. Chrysomelidae) were reared on potato plants at the Crop Research Institute. The larvae were hand collected from the flies prior to the experiment and segregated using head capsule measurements. Larvae 4 th instars $2-2.4 \mathrm{~mm}$ long were used in bioassays.

Supercritical extraction. Home-made extraction equipment was equipped with compressor 560.0007 (NovaSwiss), pressure regulation unit 560.0009 (NovaSwiss) and heated extractor of $150 \mathrm{ml}$ volume and $30 \mathrm{~mm}$ I.D. (VSK Pardubice, $\mathrm{CR})$. Carbon dioxide from pressure bottle was pumped by the compressor to the extractor filled with $50 \mathrm{~g}$ of savory. The entrainer, ethanol, was pumped by high-pressure isocratic pump Alpha 10
(ECOM Praha, CR) and mixed with the $\mathrm{CO}_{2}$ stream to the extractor, which flow rate was adjusted to $1.4 \mathrm{~g} \mathrm{~min}^{-1}$. The solution flowing out of the extractor expanded in a valve to atmospheric pressure and the extract was collected in a glass trap cooled in a mixture of dry ice and ethanol, except for the experiments with entrainer, which condensed in the trap at room temperature together with the extract and was then evaporated under a stream of nitrogen. The amount of supercritical $\mathrm{CO}_{2}$ passed through the extractor was measured after its expansion by gas meter Pl 0,1 (Spectrum Skuteč, CR) connected to the trap and converted to mass units; in each extraction run it was close to $700 \mathrm{~g}$ ( $400 \mathrm{~L}$ of expanded gas). As the extraction was controlled rather by phase equilibrium than by diffusion, the extraction time, which was between 8 and $9 \mathrm{~h}$, could be shortened by increasing the solvent flow rate.

Three types of extract were prepared using the benefit of variable solvent power of supercritical $\mathrm{CO}_{2}$ under different experimental conditions:

- oleoresin extracted with pure $\mathrm{CO}_{2}$ at $28 \mathrm{MPa}$ and $50^{\circ} \mathrm{C}$ (SFE1),

- extract rich in essential oil, extracted with pure $\mathrm{CO}_{2}$ at $12 \mathrm{MPa}$ and $50^{\circ} \mathrm{C}$ (SFE2),

- extract enriched with polar components, extracted with $\mathrm{CO}_{2}$ modified by acetone (4.3 wt.\%) at $28 \mathrm{MPa}$ and $50^{\circ} \mathrm{C}$ (SFE3).

Soxhlet extraction. Dry plant material (10-12 g) was extracted with $250 \mathrm{ml}$ ethanol (SE) or hexane (SH) in Soxhlet apparatus for $7 \mathrm{~h}$. The solvent was removed from the extract using a vacuum evaporator.

Hydrodistillation procedure (HD). Dry plant $(30 \mathrm{~g})$ was immersed in $300 \mathrm{ml}$ water and distilled in an Unger-type apparatus for $5 \mathrm{~h}$. The volume of collected essential oil was measured in the calibrated capillary of the apparatus and converted to mass using the savory oil density $0.92 \mathrm{~g} / \mathrm{ml}$.

Insecticidal activity. Acute toxicity of extracts, measured as mortality after $24 \mathrm{~h}$, was determined by topical application to early fourth instars larvae $S$. littoralis and $L$. decemlineata, larvae and adults $M$. domestica, and 4th instars C. quinquefasciata larvae.

For larvae $S$. littoralis and $L$. decemlineata and adults $M$. domestica the following method was used. The extracts were dissolved in acetone as a carrier and each larva received $1 \mu \mathrm{l}$ of the solution 
per treatment, with acetone alone as the control. The range of five doses $(500,250,125,50$ and 10 $\mu \mathrm{g}$ for $L$. decemlineata and M. domestica or 400, $200,120,50,20 \mu \mathrm{g}$ for $S$. littoralis) that were used to establish the lethal doses was determined by preliminary screening. Four replications of 20 larvae or adults were tested per dose. The doses were applied to the dorsum using a repeating topical dispenser attached to $100 \mu \mathrm{l}$ syringes. All treated larvae or adults from each replicate were transferred to relevant diet in plastic boxes $(10 \times 10 \times 7 \mathrm{~cm})$. The boxes were placed for $24 \mathrm{~h}$ in a growth chamber $\left(\mathrm{L} 16: \mathrm{D} 8,25^{\circ} \mathrm{C}\right)$. Death was recorded when the larvae or adults did not respond to prodding with forceps.

For larvae $M$. domestica the following dipping method was used. The larvae were randomized into groups (20larvae/group) and reared in separate rearing boxes. Solutions of extracts were prepared in a glass bowl by the serially 2-fold dilution method using absolute acetone as the solvent. By initial screening to approximate the range of active concentrations five concentrations were selected $(500,400,300,150$ and $80 \mu \mathrm{g} / \mathrm{ml})$ and used to establish the lethal concentration. The larvae of each group were wrapped in a voile cloth and gently dipped into extract solution, whereas those of the controls were dipped in acetone. After being dipped for exactly $30 \mathrm{~s}$, the larvae were transferred to the rearing box containing food and placed in a growth chamber $\left(\mathrm{L} 16: \mathrm{D} 8,26^{\circ} \mathrm{C}\right)$. The mortality of larvae was assessed after $24 \mathrm{~h}$ by touching each one with a paint brush, and those not responding were considered death. The dipping experiments were carried out in three replications.

Mosquito larvicidal assays were carried out according to WHO standard procedures (1996), with slight modifications. The extracts were diluted in dimethyl sulphoxide (DMSO) to prepare a serial dilution of test dosage $(500,250,125,62.5$ and $31.3 \mu \mathrm{g} / \mathrm{ml}$ ). Early fourth instar larvae of C. quinquefasciata were selected and transferred in $25 \mathrm{ml}$ of distilled water.

For experimental treatment, $1 \mathrm{ml}$ of serial dilutions was added to $224 \mathrm{ml}$ of distilled water in a 500-ml glass bowl and shaken lightly to ensure a homogenous test solution. The selected larvae were transferred in distilled water into a bowl of prepared test solution with final surface area $125 \mathrm{~cm}^{2}$ (25 larvae/beaker). Four replicates were run simul- taneously with at least five dosages providing a range of $0-100 \%$ mortality. The assays were placed in a growth chamber $\left(\mathrm{L} 16: \mathrm{D} 8,26^{\circ} \mathrm{C}\right)$. The mortality was determined after $24 \mathrm{~h}$ of exposure, during which time no food was offered to the larvae.

Probit analysis (Finney, 1971) was used to determine $\mathrm{LD}_{50}, \mathrm{LD}_{90}$, and the corresponding $95 \%$ confidence intervals.

Gas chromatography. The composition of volatile compounds in all extracts was determined using GC-MS and GC-FID. The identification of compounds was based on the comparison of their mass spectra and retention indices with published results (Adams, 2007) and, where possible, with authentic compounds.

GC-MS: the analyses were performed on Agilent 6890 gas chromatograph coupled to Agilent 5973 mass spectrometer operating in $70 \mathrm{eV}$ ionization mode. DB-5MS column $(30 \mathrm{~m} \times 0.25 \mathrm{~mm} \times$ $0.25 \mu \mathrm{m})$ was used with $\mathrm{He}$ as a carrier gas.

GC-FID analyses were performed on Hewlett Packard 5890 gas chromatograph equipped with DB-5 column $(30 \mathrm{~m} \times 0.25 \mathrm{~mm} \times 1 \mu \mathrm{m})$ and using $\mathrm{N}_{2}$ as a carrier gas.

The concentration of extract components was calculated from the GC-FID results and expressed in two ways: as the mass of compound in unit mass of extract $(\mathrm{mg} / \mathrm{g})$ and as the mass of compound divided by the sum of the masses of all identified essential oil components (\%).

\section{RESULTS AND DISCUSSION}

Extracts from plants contain a number of biologically active substances. Their qualitative and quantitative composition closely depends on the applied extraction technique and operating conditions. The extraction yields were performed in duplicate with the averaged values shown in Fig. 1. The highest extraction yield from aerial parts of $S$. hortensis, $9.6 \pm 0.5$ wt.\% (dry weight), was obtained by Soxhlet extraction with ethanol. The lowest extraction yield was observed for hydrodistillation $(1.9 \pm 0.2$ wt.\%, DW). The extraction yields obtained with supercritical carbon dioxide varied between 3 and $4 \mathrm{wt} . \%$ in dependence on extraction conditions, with uncertainty less than $0.2 \%$. The yield of Soxhlet extraction with hexane, $4.5 \pm 0.2 \mathrm{wt} . \%$, DW, was comparable with SFE1 extract. Similar differences in extraction yields in dependence on extraction 
techniques were found also in previous studies (Esquível et al., 1999; Moldão-Martins et al., 2000; Sefidkon et al., 2006).

The effect of extraction technique on the extract composition is shown in Table 1. Our attention was focused on monoterpenoids, which are generally considered as contact and respiration poisons (Isman, 2000; Pavela, 2007a); they are responsible

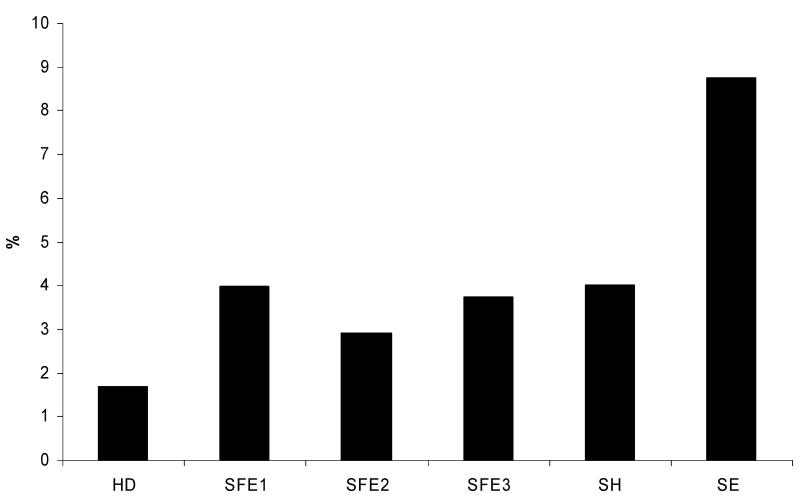

Fig. 1. The yields of extracts from Satureja hortensis (\% w/w) obtained by different methods: HD, hydrodistillation; SFE, supercritical fluid extraction at $50^{\circ} \mathrm{C}\left(1, \mathrm{CO}_{2}\right.$ at $28 \mathrm{MPa}$; $2, \mathrm{CO}_{2}$ at $12 \mathrm{MPa} ; 3, \mathrm{CO}_{2}$ with ethanol at $\left.28 \mathrm{MPa}\right) ; \mathrm{S}$, Soxhlet extraction with hexane ( $\mathrm{SH})$ and ethanol (SE). for short-term mortality in insect. Biological activity of individual extracts was therefore evaluated as lethal doses determined by topical application in short-term tests. According to the results of gas chromatographic analysis, the maximum concentration of terpenic substances was in the hydrodistillate (67.4 wt.\%), followed by supercritical extracts SFE1, SFE2 and SFE3 (46.6, 46.5 and 39.7 wt. $\%$, respectively). The concentration of volatile terpenoids in $\mathrm{SH}$ and $\mathrm{SE}$ extracts was low (22.9 and 12.8 wt.\%, respectively) because a part of them escaped during the solvent evaporation. The major components in all extracts were carvacrol and, except for the Soxhlet extracts, $\gamma$-terpinene.

The resulting insecticidal activity against four kinds of pests is listed in Table 2. The most efficient extracts are HD and SFE2. They show the lowest values of lethal doses, often overlapping in the $95 \%$ confidence interval. The efficiency of SFE1 extract was still good, though significantly lower (see the confidence intervals in Table 2). Extracts SFE3, SH and SE show unsatisfactory efficiencies with lethal doses often higher than the

Table 1. Chemical composition of savory essential oil (HD), supercritical extracts (SFE1-3) and extracts with organic solvents (SH and SE)

\begin{tabular}{|c|c|c|c|c|c|c|c|c|c|c|c|c|c|}
\hline \multirow{2}{*}{ Compounds } & \multirow{2}{*}{$\begin{array}{c}t_{\mathrm{R}}^{\mathrm{a}} \\
(\mathrm{min})\end{array}$} & \multicolumn{2}{|c|}{$\mathrm{HD}$} & \multicolumn{2}{|c|}{ SFE1 } & \multicolumn{2}{|c|}{ SFE2 } & \multicolumn{2}{|c|}{ SFE3 } & \multicolumn{2}{|l|}{$\mathrm{SH}$} & \multicolumn{2}{|c|}{ SE } \\
\hline & & $(\mathrm{mg} / \mathrm{g})^{\mathrm{b}}$ & $(\%)$ & $(\mathrm{mg} / \mathrm{g})^{\mathrm{b}}$ & $(\%)$ & $(\mathrm{mg} / \mathrm{g})^{\mathrm{b}}$ & $(\%)$ & $(\mathrm{mg} / \mathrm{g})^{\mathrm{b}}$ & $(\%)$ & $(\mathrm{mg} / \mathrm{g})^{\mathrm{b}}$ & $(\%)$ & $(\mathrm{mg} / \mathrm{g})^{\mathrm{b}}$ & $(\%)$ \\
\hline$\alpha$-Thujene & 4.98 & 6.00 & 0.9 & 2.01 & 0.4 & 2.14 & 0.5 & & & & & & \\
\hline$\alpha$-Pinene & 5.17 & 5.73 & 0.9 & 1.75 & 0.4 & 1.89 & 0.4 & & & & & & \\
\hline$\beta$-Pinene & 6.35 & 2.59 & 0.4 & 1.02 & 0.2 & 1.06 & 0.2 & & & & & & \\
\hline Myrcene & 6.62 & 10.67 & 1.6 & 5.03 & 1.1 & 5.43 & 1.2 & 0.23 & 0.1 & & & & \\
\hline$\alpha$-Phellandrene & 7.17 & 1.57 & 0.2 & 0.42 & 0.1 & 0.80 & 0.2 & & 0.0 & & & & \\
\hline$\alpha$-Terpinene & 7.51 & 23.62 & 3.5 & 5.79 & 1.2 & 9.76 & 2.1 & 0.46 & 0.1 & & & & \\
\hline$p$-Cymene & 7.76 & 31.80 & 4.7 & 16.27 & 3.5 & 20.15 & 4.3 & 4.98 & 1.3 & 1.46 & 0.6 & & \\
\hline Limonene & 7.91 & 3.06 & 0.5 & 0.30 & 0.1 & & & & & & & & \\
\hline$\beta$-Phellandrene & 7.97 & 0.65 & 0.1 & & & & & & & & & & \\
\hline$\gamma$-Terpinene & 8.91 & 247.09 & 36.7 & 128.12 & 27.5 & 135.89 & 29.2 & 39.32 & 9.9 & 8.65 & 3.8 & & \\
\hline Terpinen-4-ol & 13.67 & 0.95 & 0.1 & & & & & & & & & & \\
\hline Ascaridole & 16.13 & & & 0.66 & 0.1 & & & & & & & & \\
\hline Thymoquinone & 16.55 & & & 9.50 & 2.0 & 4.74 & 1.0 & 14.28 & 3.6 & 10.11 & 4.4 & & \\
\hline Thymol & 18.30 & & & 0.49 & 0.1 & & & 1.57 & 0.4 & & & 1.79 & 1.4 \\
\hline Carvacrol & 18.66 & 323.96 & 48.1 & 282.04 & 60.6 & 268.89 & 57.9 & 319.46 & 80.5 & 199.85 & 87.5 & 125.60 & 98.0 \\
\hline$\beta$-Caryophyllene & 23.61 & 5.01 & 0.7 & 3.51 & 0.8 & 3.91 & 0.8 & 3.52 & 0.9 & 2.02 & 0.9 & & \\
\hline$\beta$-Bisabolene & 27.26 & 11.25 & 1.7 & 8.22 & 1.8 & 10.05 & 2.2 & 8.42 & 2.1 & 6.35 & 2.8 & 0.81 & 0.6 \\
\hline $\begin{array}{l}\text { Thymohydro } \\
\text { quinone }\end{array}$ & 28.95 & & & 0.56 & 0.1 & & & 4.41 & 1.1 & & & & \\
\hline
\end{tabular}

\footnotetext{
${ }^{\text {a }}$ Retention time.

${ }^{\mathrm{b}} \mathrm{mg}$ compound/g extract.
} 
Table 2. Insecticidal activity of Satureja hortensis extracts against four pests

\begin{tabular}{|c|c|c|c|c|c|c|c|c|c|c|}
\hline \multirow{3}{*}{ Extracts } & \multicolumn{4}{|c|}{ Musca domestica } & \multirow{2}{*}{\multicolumn{2}{|c|}{$\begin{array}{c}\text { Culex } \\
\text { quinquefasciatus } \\
\text { Larvae }\end{array}$}} & \multirow{2}{*}{\multicolumn{2}{|c|}{$\begin{array}{c}\text { Spodoptera } \\
\text { littoralis }\end{array}$}} & \multirow{2}{*}{\multicolumn{2}{|c|}{$\begin{array}{c}\text { Leptinotarsa } \\
\text { decemlineata }\end{array}$}} \\
\hline & \multicolumn{2}{|c|}{ Larvae } & \multicolumn{2}{|c|}{ Adults } & & & & & & \\
\hline & $\begin{array}{c}\mathrm{LC}_{50} \\
(\mu \mathrm{g} / \mathrm{ml})\end{array}$ & $\begin{array}{c}\mathrm{LC}_{90} \\
(\mu \mathrm{g} / \mathrm{ml})\end{array}$ & $\begin{array}{l}\mathrm{LD}_{50} \\
(\mu \mathrm{g})\end{array}$ & $\begin{array}{l}\mathrm{LD}_{90} \\
(\mu \mathrm{g})\end{array}$ & $\begin{array}{c}\mathrm{LC}_{50} \\
(\mu \mathrm{g} / \mathrm{ml})\end{array}$ & $\begin{array}{c}\mathrm{LC}_{90} \\
(\mu \mathrm{g} / \mathrm{ml})\end{array}$ & $\begin{array}{l}\mathrm{LD}_{50} \\
(\mu \mathrm{g})\end{array}$ & $\begin{array}{l}\mathrm{LD}_{90} \\
(\mu \mathrm{g})\end{array}$ & $\begin{array}{l}\mathrm{LD}_{50} \\
(\mu \mathrm{g})\end{array}$ & $\begin{array}{l}\mathrm{LD}_{90} \\
(\mu \mathrm{g})\end{array}$ \\
\hline SFE1 & $\begin{array}{c}257 \\
(216-298)^{\mathrm{a}}\end{array}$ & $\begin{array}{c}481 \\
(390-526)^{\mathrm{a}}\end{array}$ & $\begin{array}{c}98 \\
(80-130)^{\mathrm{a}}\end{array}$ & $\begin{array}{c}120 \\
(115-138)^{\mathrm{a}}\end{array}$ & $\begin{array}{c}65 \\
(59-68)^{\mathrm{a}}\end{array}$ & $\begin{array}{c}78 \\
(69-82)^{\mathrm{a}}\end{array}$ & $\begin{array}{c}98 \\
(76-125)^{\mathrm{a}}\end{array}$ & $\begin{array}{c}123 \\
(110-138)^{\mathrm{a}}\end{array}$ & $\begin{array}{c}60 \\
(50-70)^{\mathrm{a}}\end{array}$ & $\begin{array}{c}103 \\
(98-120)^{\mathrm{a}}\end{array}$ \\
\hline SFE2 & $\begin{array}{c}193 \\
(164-228)^{\mathrm{a}}\end{array}$ & $\begin{array}{c}383 \\
(332-409)^{\mathrm{a}}\end{array}$ & $\begin{array}{c}38 \\
(31-40)^{\mathrm{a}}\end{array}$ & $\begin{array}{c}48 \\
(44-59)^{\mathrm{a}}\end{array}$ & $\begin{array}{c}45 \\
(42-48)^{\mathrm{a}}\end{array}$ & $\begin{array}{c}53 \\
(49-60)^{\mathrm{a}}\end{array}$ & $\begin{array}{c}31 \\
(28-38)^{\mathrm{a}}\end{array}$ & $\begin{array}{c}52 \\
(48-61)^{\mathrm{a}}\end{array}$ & $\begin{array}{c}28 \\
(20-33)^{a}\end{array}$ & $\begin{array}{c}85 \\
(82-91)^{\mathrm{a}}\end{array}$ \\
\hline SFE3 & $>500$ & $>500$ & $\begin{array}{c}370 \\
(315-450)^{\mathrm{a}}\end{array}$ & $\begin{array}{c}490 \\
(435-510)^{\mathrm{a}}\end{array}$ & $\begin{array}{c}82 \\
(71-96)^{\mathrm{a}}\end{array}$ & $\begin{array}{c}102 \\
(93-115)^{\mathrm{a}}\end{array}$ & $\begin{array}{c}360 \\
(303-426)^{\mathrm{a}}\end{array}$ & $>400$ & $\begin{array}{c}30 \\
(20-32)^{\mathrm{a}}\end{array}$ & $\begin{array}{c}86 \\
(80-95)^{\mathrm{a}}\end{array}$ \\
\hline $\mathrm{SH}$ & $>500$ & $>500$ & $>500$ & $>500$ & $\begin{array}{c}290 \\
(248-310)^{\mathrm{a}}\end{array}$ & $\begin{array}{c}380 \\
(350-398)^{\mathrm{a}}\end{array}$ & $>400$ & $>400$ & $\begin{array}{c}44 \\
(33-59)^{\mathrm{a}}\end{array}$ & $\begin{array}{c}102 \\
(98-130)^{\mathrm{a}}\end{array}$ \\
\hline SE & $>500$ & $>500$ & $>500$ & $>500$ & $\begin{array}{c}381 \\
(350-402)^{\mathrm{a}}\end{array}$ & $\begin{array}{c}455 \\
(420-483)^{\mathrm{a}}\end{array}$ & $>400$ & $>400$ & $\begin{array}{c}78 \\
(73-86)^{\mathrm{a}}\end{array}$ & $\begin{array}{c}240 \\
(231-265)^{2}\end{array}$ \\
\hline HD & $\begin{array}{c}78 \\
(70-96)^{\mathrm{a}}\end{array}$ & $\begin{array}{c}138 \\
(128-156)^{\mathrm{a}}\end{array}$ & $\begin{array}{c}35 \\
(25-42)^{\mathrm{a}}\end{array}$ & $\begin{array}{c}45 \\
(40-48)^{\mathrm{a}}\end{array}$ & $\begin{array}{c}36 \\
(33-46)^{\mathrm{a}}\end{array}$ & $\begin{array}{c}48 \\
(47-53)^{\mathrm{a}}\end{array}$ & $\begin{array}{c}45 \\
(34-59)^{\mathrm{a}}\end{array}$ & $\begin{array}{c}62 \\
(55-73)^{\mathrm{a}}\end{array}$ & $\begin{array}{c}22 \\
(20-32)^{\mathrm{a}}\end{array}$ & $\begin{array}{c}52 \\
(47-63)^{\mathrm{a}}\end{array}$ \\
\hline
\end{tabular}

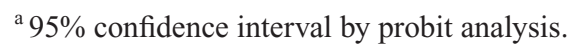

maximum tested dose.

The total content of all monoterpenoids and their suitable combination seem to be most responsible for mortality of $M$. domestica. As shown in Table 2, the hydrodistillate and SFE2 were most efficient, while Soxhlet extracts showed the least efficiency. Lee et al. (1997) estimated lethal doses of several monoterpenoids for adults of $M$. domestica. For topical application the authors found that $\mathrm{LD}_{50}$ was in the range of $60-125 \mu \mathrm{g} /$ insect for carvacrol and 154-305 $\mu \mathrm{g}$ /insect for $\gamma$-terpinene (95\% CI). Hummelbrunner and Isman (2001) stated $\mathrm{LD}_{50}$ of carvacrol in the range of $38-48 \mu \mathrm{g}$ per larva in $S$. litura larvae. However, our results indicate a much lower sensitivity to SFE. For example, $\mathrm{LD}_{50}$ corresponding with the dose $114.8 \mu \mathrm{g}$ per larva was determined for SFE3. These differences in efficiency of extracts from $S$. hortensis can be ascribed to possible inter-species difference in sensitivity, general vitality of the larvae, as well as different total content of all terpenic substances. Carvacrol combination with $\gamma$-terpinene or other monoterpenoid substances, a very good synergistic effect was shown (Hummelbrunner and Isman, 2001), which needs to be further studied.

In general, it can be stated that the extraction with carbon dioxide at $12 \mathrm{MPa}$ and $50^{\circ} \mathrm{C}$ is a promising extraction method yielding extracts of high efficiency similar to the efficiency of the extract obtained by hydrodistillation and significantly more efficient than the extracts obtained using the standard extraction methods. With respect to the fact that the extraction yield is higher by $73 \%$ and the energy demands of the extraction process are lower than in distillation, this environmentally safe method can be viewed as suitable for the extraction of essential oils used for preparation of botanical insecticides.

Nevertheless, the extracts from S. hortensis may contain polyphenolic substances (Barberan, 1986; Regnault-Roger et al., 2004), which are of comparable importance in reduction of pest populations (Shalaby et al., 1998; Pavela, 2007b) as the effect on immediate mortality examined in this paper. Therefore, further tests need to be performed in order to determine repellency, antifeedancy and/or growth inhibition effects of the compared extracts on insects.

\section{ACKNOWLEDGEMENTS}

This study was supported by grants from the Ministry of Education, Youth and Sports (project 2B06049).

\section{REFERENCES}

Adams, R. P. (2007) Identification of Essential Oil Components by Gas Chromatography/Mass Spectrometry. 4th 
edition. Allured Publishing Corporation, Illinois. 804 pp.

Alkofahi, A., J. K. Rupprecht, J. E. Anderson, J. L. Mclaughlin, K. L. Mikolajczak and B. A. Scott (1989) Search for new pesticides from higher plants. In Insecticides of Plant Origin (ACS Symposium Series) (J. T. Arnason, B. J. R. Philogene and P. Morand, eds.). American Chemical Society, Washington, D.C., pp. 25-43.

Barberan, F. A. T. (1986) The flavonoids from the Labiateae. Fitoterapia 57: 67-95.

Darbour, N., F. Baltassat, J. Raynaud and J. Pellecuer (1990) Flavonoid glycosides in leaves of Satureja hortensis L. (Labiateae). Pharma. Acta Helvet. 65: 239-240.

Deans, S. G. and K. P. Svoboda (1989) Antibacterial activity of summer savory (Satureja hortensis L.) essential oil and its constituents. J. Hortic. Sci. 64: 205-210.

Esquível, M. M., M. A. Ribeiro and M. G. Bernardo-Gil (1999) Supercritical extraction of savory oil: study of antioxidant activity and extract characterization. J. Supercrit. Fluids 14: 129-138.

Finney, D. J. (1971) Probit Analysis. Cambridge University Press, London. 333 pp.

Hummelbrunner, L. A. and M. B. Isman (2001) Acute, sublethal, antifeedant, and synergistic effects of monoterpenoid essential oil compounds on tobacco cutworm, Spodoptera litura (Lep., Noctuidae). J. Agric. Food Chem. 49: 715-720.

Isman, M. B. (2000) Plant essential oils for pest and disease management. Crop Prot. 19: 603-608.

Lee, S., R. Tsao, C. Peterson and J. R. Coats (1997) Insecticidal activity of monoterpenoids to western corn rootworm (Coleoptera: Chrysomelidae), twospotted spider mite (Acari: Tetranychidae), and house fly (Diptera: Muscidae). J. Econ. Entomol. 90: 883-892.

Moldão-Martins, M., A. Palavra, M. L. Beirão da Costa and M. G. Bernardo-Gil (2000) Supercritical $\mathrm{CO}_{2}$ extraction of Thymus zygis L. subsp. Sylvestris aroma. J. Supercrit. Fluids 18: 25-34.

Pavela, R. (2005) Insecticidal activity of some essential oils against larvae of Spodoptera littoralis. Fitoterapia 76:
691-696.

Pavela, R. (2006) Insecticidal activity of essential oils against cabbage aphid (Brevicoryne brassicae). J. Essent. Oil Bearing Plants 9: 99-106.

Pavela, R. (2007a) Possibilities of botanical insecticide exploitation in plant protection. Pest Technol. 1: 47-52.

Pavela, R. (2007b) The feeding effect of polyphenolic compounds on the Colorado potato beetle [Leptinotarsa decemlineata (Say)]. Pest Technol. 1: 81-84.

Regnault-Roger, C., M. Ribodeau, A. Hamraoui, I. Bareau, P. Blanchard, M. I. Gil-Munoz and F. T. Barberan (2004) Polyphenolic compounds of Mediterranean Lamiaceae and investigation of orientational effects on Acanthoscelides obtectus (Say). J. Stor. Prod. Res. 40: 395408.

Sampson, B. J., N. Tabanca, N. Kirimer, B. Demirci, K. H. Can Baser, I. A. Khan, J. M. Spiers and D. E. Wedge (2005) Insecticidal activity of 23 essential oils and their major compounds against adult Lipaphis pseudobrassicae (Davis) (Aphididae: Homoptera). Pest Man. Sci. 61: 1122-1128.

Sefidkon, F. and Z. Jamzad (2005) Chemical composition of the essential oil of three Iranian Satureja species ( $S$. mutica, S. macrantha and S. intermedia). Food Chem. 91: $1-4$.

Sefidkon, F., Z. Jamzad and M. Mirza (2004) Chemical variation in the essential oil of Satureja sahendica from Iran. Food Chem. 88: 325-328.

Sefidkon, F., K. Abbasi and G. B. Khaniki (2006) Influence of drying and extraction methods on yield and chemical composition of the essential oil of Satureja hortensis. Food Chem. 99: 19-23.

Shalaby, A. A., K. A. Allam, A. A. Mostafa and S. M. Fahmy (1998) Insecticidal properties of citrus oils against Culex pipens and Musca domestica. J. Egypt. Soc. Parasitol. 28: 595-606.

WHO (1996) Report of the WHO Informal Consultation on the Evaluation and Testing of Insecticides. CID/ WHOPEWS/IC/ 96.1., p. 69. 